\title{
1600-talsmänniskan och den straffande Guden
}

\section{Av Olle Larsson, doktorand i historia}

\author{
Länk till presentation av Olle Larsson
}

" Herren skall låta pestilentie loda vid dig, till dess han gör ända med dig på landena dit du kommer att intaga det. Herren skall slå dig med svullnad, skälvo, hetta, bränno, torrhet och blekhet, och skall förfölja dig, till dess han förgör dig ".

Kan man som historiker förstå de människor från förr som man möter i sitt källmaterial? Svaret på denna fråga varierar naturligtvis. Självklart beror det på det kulturella och tidsmässiga avstånd som ligger mellan oss och dem. Det är således ofta lättare att förstå en människa från det tidiga 1900-talet än en person som levde under den svenska stormaktstiden. 1900-talsmänniskan delar vanligtvis vår egen sekulariserade syn på världen medan vår vän från 1600-talet trodde på Gud. Han levde i ett samhälle i vilket religionen satte ramarna för vad som var möjligt att tänka och tro. För att förstå honom måste vi alltså försöka sätta oss in i hans tankevärld. Jag skall här försöka att lyfta fram en aspekt av 1600-talsmänniskans verklighet, nämligen hans syn på Gud.

Inledningen till denna artikel är hämtad från Gustav Vasas bibel, närmare bestämt från femte Moseboks tjugoåttonde kapitel. Här framträder tydligt bilden av en Gud som kunde straffa människorna för deras synder. I 1600-talets Sverige var denna gudsbild den förhärskande. Motgångar och olyckor tolkades som Guds straff. Ofta använde han sig av naturen för att kommunicera med människorna men också för att straffa dem. Oväder, missväxt, pest, hungersnöd, krig och social oro betraktades som tecken på Guds vrede. Straffen drabbade ofta kollektivt och Gud gjorde då ingen skillnad på skyldiga och oskyldiga. Det fanns en stark koppling mellan synd och straff.

Bakgrunden till tanken att Gud kunde straffa ett helt land för folkets synder kommer tydligt till uttryck i bibeln, främst i det Gamla Testamentet. Tanken utgår från att det rådde ett kontraktsförhållande mellan människorna och Gud. Straffen kom då människorna, genom sina synder, bröt det ingångna kontraktet och utgick vanligen i form av de tre klassiska landsplågorna krig, pest och hungersnöd. Straffen betraktades som tillrättavisningar av människorna. Laurentius Petri menade att pesten var "ett faderligt ris och barna age, där med Gud oss lika som sin barn tuktar och agar till bättring, på det vi det eviga straffet och fördömelsen undkomma måge ". Hela 1600-talet igenom var denna så kallade vedergällningsdoktrin central. Religionen i det stormaktstida Sverige, ortodoxin, var stark gammaltestamentligt orienterad. Ett led i den svenska överhetens krigspropaganda var att Sverige tagit över Israels roll som det utvalda folket. Detta kontraktsförhållande mellan svenskarna och Gud krävde en obetingad lydnad av hans lag. Detta innebar att de tio budorden blev oerhört viktiga.

Mot slutet av 1600-talet började en ny världsbild göra sig gällande i de lärda kretsarna i Sverige. Naturen började nu att uppfattas som lagbunden och utrymmet för Guds direkta ingripande i naturen minskade således. Under 1700-talet minskar de religiösa förklaringarna till missväxt, sjukdomar och andra olyckor i betydelse och inomvärldsliga förklaringar blir vanligare. Nu förändrades gudsbilden och vedergällningsdoktrinen började spela ut sin roll. Den stränge, gammaltestamentliga Guden fick lämna scenen och ge plats för en mildare, förlåtande och mer kärleksfull Gud. Fortfarande skulle det emellertid dröja innan Gud och religionen helt konkurrerades ut av mer sekulariserade tankemönster. 
Olle Larsson, '1600-talsmänniskan och den straffande Guden'

rubriken 'Gud straffade 1600-talsmänniskan')

http://www.vxu.se/hum/publ/humanetten/nummer1/art9715.html[2010-05-26 14:32:17] 